\title{
Problems of forming a positive consciousness of people in the conditions of digitalization of society
}

\author{
Nikolay Saraev ${ }^{1 *}$, Gennady Pratsko $^{1}$, Irina Korolenko², Ekaterina Marchenko ${ }^{3}$ \\ ${ }^{1}$ Rostov Branch of the Russian State University of Justice, Don State Technical University, Rostov- \\ on-Don, Russian Federation \\ ${ }^{2}$ Rostov State University of Economics (RSUE), Rostov-on-Don, Russian Federation \\ ${ }^{3}$ Rostov State University of Railway Transport, Rostov-on-Don, Russian Federation
}

\begin{abstract}
The insufficient level of legal awareness of Russian citizens is a serious problem of ensuring the rule of law and the rule of law, forms a general destructive background that prevents the formation of an effective system for the protection of human and civil rights and freedoms. Important factors that influence the formation of a positive legal consciousness are the quality level of education and training in educational institutions, the consolidation and development of the basics of legal consciousness in students, changes in the quality of education and training in educational institutions, including the consolidation and development of the tradition of respect for the law as the prevailing model of social behavior.

It is at school age that active legal socialization takes place. The main burden in the formation of values for law-abiding behavior should be taken by school legal education.

The purpose of the study was to study the regularities of the educational process for the formation of students ' positive legal awareness, the development of value orientations on the inadmissibility of illegal manifestations in the future.

In the complex of methodological approaches developed in Russian pedagogy, the system-forming and adequate task of forming the legal culture of students is the methodology of the personality-oriented approach and the set of interrelated pedagogical principles of its implementation.

These studies indicate the need to review the vector of measures carried out in accordance with the Fundamentals of State Policy aimed at minimizing nihilism. In the context of the introduction of digital technologies that provide access to legal information, minors relate the surrounding formations from the point of view of the law, focusing not on the process, but on the final result. However, the manifestations of the discrepancy between the legal reality and the fixed normative attitudes cause legal frustration, which often manifests itself in sthenic forms.

The results of the study allowed us to come to a conclusion about the state of legal dissatisfaction of minors, due to the discrepancy between the theoretical provisions of the law and law enforcement at the active level of the value-semantic personal sphere. For the purpose of more in-depth
\end{abstract}

\footnotetext{
*Corresponding author: snv_571978@mail.ru
} 
scientific research, we believe it is appropriate to designate this social phenomenon as legal deprivation of minors.

The specifics of the content of legal education allow us to implement it in the following forms: subject, inter-subject, educational, institutional, project. The most appropriate approach is an integrated approach that combines all of the above forms.

\section{Introduction}

The current period of development of public relations in the Russian Federation is complex and contradictory, due to the lack of a unified legal doctrine that prioritizes systemic compliance with legislation, and is characterized by the strategic need to bring the domestic legal system in line with economic and social formations [1].

At the same time, one of the most important conditions for the effective functioning of the authorities of a democratic state is the national legal system that corresponds to modern economic, social, ideological and other formations. It is the qualitative characteristics of such fundamental elements of the legal system as law-making and law enforcement that determine the content side of the legal consciousness of a citizen's personality.

The peculiarities of legal awareness as a legal phenomenon are not only in the formation of ideas about the current system of legal regulation and the psychological perception of legal existence, as practice shows, the variability of law-abiding behavior is directly influenced by the emerging internal attitudes.

The process of transformation of legal feelings and emotions into behavioral acts based on the observance of the law is such a fundamental principle of legal activity as legality. It is the state of legality that is the cementing material that forms the system of guarantees of human and civil rights and freedoms.

It is natural that the criteria of the state of legality, that is, the regularities of the system of behavioral acts mediated externally by citizens on the basis of the mental perception of law, are indicators of the effectiveness of the functioning of the judicial system and the activities of executive authorities. Thus, according to the federal program for the development of the judicial system until 2024, as an indicator of the effectiveness of the implementation of the document, the trend of increasing the number of citizens who positively characterize the work of the courts is determined. And, in accordance with Presidential Decree No. 68 of February 4, 2021, regulating the assessment of the effectiveness of the activities of senior regional officials, the main indicator of law enforcement is the trust of citizens.

The legal imbalance that has reached a critical point, burdened by a huge array of outdated legislation, does not allow the system of state bodies to form a single vector of law enforcement, which often seeks to defend public interests by erroneous populist methods of implementing long-term programs. In such circumstances, the loss of life prospects by a significant part of Russian society will contribute to the formation and spread of illegal behavior patterns, the dominance of criminal structures in resolving important political and economic issues.

The most significant in this regard are the results of a study conducted by the Federal Security Service in May 2020, according to which the level of respondents who noted a lack of confidence in law enforcement agencies increased from $45 \%$ in 2017 to $66.7 \%$ in 2019. The majority of respondents reported a lack of confidence in the judiciary $(55 \%)$, while two-thirds $(66.9 \%)$ are not confident in the independence and objectivity of the judicial system. 
The insufficient level of legal awareness of the population forms a general destructive background for the development of delinquent practices, which primarily applies to minors. In particular, the participation of minors in unauthorized rallies indicates the need to implement additional measures aimed at forming a positive legal consciousness.

\section{Materials and methods}

The above-mentioned problems, which set the task of finding the reasons and conditions for the formation of a social and legal background of a positive legal consciousness, unfortunately, were not fully resolved by the Fundamentals of the State Policy of the Russian Federation in the Field of Legal Literacy and Legal Awareness of Citizens adopted in May 2011. The document defines the following as the main facts influencing the formation of a positive legal consciousness:

- the nature and quality of the educational process;

- the level of education that provides for the development of legal foundations by students;

- efficiency and professionalism of judicial and law enforcement agencies.

However, the participation of minors in unauthorized rallies indicates the need to implement additional measures aimed at creating a positive legal awareness.

Thus, it is important to rethink the complex of factors that determine the modern variability of behavioral legal stereotypes, their relationship with compliance with the requirements of the rule of law and the impact on the formation of a positive legal consciousness of citizens.

The study is based on the dialectical method of cognition of phenomena that influence the formation of a positive legal consciousness of students in the process of their education and upbringing. The research methodology includes systematic, logical general scientific methods, as well as private scientific methods: questionnaires, the method of expert assessments, comparative legal analysis of normative legal acts and scientific sources covering the problem under consideration. The empirical base of the study was made up of survey data from 100 experts from among citizens raising children-students of general education institutions, 100 college students. The object of the study: the regularities of the pedagogical and educational process for the formation of students ' positive legal awareness. Subject of research: pedagogical and educational methods for the formation of students ' ideas about law-abiding behavior, the development of value orientations on the inadmissibility of illegal behavior.

\section{Results}

Today, in Russia, in the context of cardinal state and political transformations, the main functional burden for their successful implementation is placed on the rule of law as the main socializing regulatory institution. Being a special transformative legal regime, only the rule of law has a unique regulatory tool that can ensure the implementation of the principles of individualization and differentiation, the effective use of the benefits and opportunities that are aimed at ensuring the genetic domestic fund.

Revealing the state of legality, one of the leading Russian legal scientists N. N. Voplenko notes that the indicators of the institute under study are indicators of legal psychology, among which the main place is occupied by the expectations of society related to the order of administration of justice, the effectiveness of the activities of government and management, with the established prestige of law in the processes of its implementation [2]. 
Of course, the radical transformations of modern state-legal, socio-economic institutions require not only a systematic study of their content, but also an explanation of the goals of the genesis of such processes, especially in the context of an obvious mimic influence on normative attitudes, law-making and law enforcement, attempts to revise doctrinal approaches to the understanding of law and the values of legal norms. Studying the mechanism of perception and reproduction of normative attitudes in modern conditions, according to the results of a survey of 150 respondents, we came to the conclusion that in the context of globalization, the information flow focused on market values does not contribute to the development of individual behavior variability, its charge carries adaptive loads focused on the dissemination of behavioral stamps of an adaptive nature. Thus, $90 \%$ of respondents are justified in non-payment of credit funds, explaining this as the reasons that arose due to the fault of the state, and $71 \%$ said that they are ready if they have the possibility of embezzlement due to their official position of large financial resources. In such conditions, the individual does not seek to comply with the requirements of regulatory guidelines, but focuses on the common facts of millions and billions of embezzlement.

The insufficient level of legal awareness of the population forms a general destructive background for the development of delinquent practices, which primarily applies to minors. In particular, this is manifested in non-performance of obligations. So, for example, only in 2 months of 2021, the debt of consumers for heat supply to resource-supplying organizations increased by $12 \%$.

Experts note that the idea of corruption and related phenomena begins to form from an early age. Unfortunately, more and more among the younger generation, the ideal of professional achievements is not spiritual and moral satisfaction with the results of their work and a sense of accomplishment, but material prosperity, and there is indifference to the means of achieving it [3].

It is at school age that an active socialization of the individual takes place, including legal socialization. It is during this period that it is necessary to form a positive legal consciousness among citizens. The main burden in the formation of values for law-abiding behavior should be taken by school legal education [4]. Within the framework of UNESCO, an approximate list of the main directions and criteria by which the dynamics of the process of legal socialization of students can be assessed has been developed. Such criteria are certain knowledge, value orientations and skills [5], which correspond to such structural elements of legal consciousness as legal ideology, legal psychology and legal behavior.

We believe that the lag in the development of law-abiding psychology, which forms legal behavior, from anti-social ideology, is interrelated with the problem of the formation of value orientations. The surrounding legal reality continuously poses problems for students the need to correlate their actions and actions with the interests of society and the order and rules established in the state. The media is saturated with information about the facts of committing corruption-related offenses, amounting to millions of rubles. The lack of organization of the formation of the legal consciousness of students leads to the fact that, finding themselves in various life situations, students often incorrectly assess the legal situation that has arisen, behave incorrectly when resolving certain legal issues, and transform into an internal factor in the development of consciousness and behavior.

The study analyzes the development of the value-semantic sphere of students of the first and third year of the law college, taking into account the elements of both the system of value orientations and personal meanings. It should be noted that if personal meanings are focused primarily on the tendency of dominating the internal significance of material and object images for the individual, then the vector of value orientations is aimed at preferring one or another form of personal activity.

Considering the value-semantic sphere as the core of the personality structure, semantic indicators characterize the significance of things and phenomena, and value orientations 
determine the vector of personal activity. In this regard, the study showed that the respondents of the two groups are focused on the final result, that is, they are interested in the model of legal relations, however, the process of ordering differs due to their knowledge of the law (Table 1).

Table 1. Information about the results of the questionnaire survey of students of the law college about the study of their value-semantic sphere

\begin{tabular}{|c|c|c|}
\hline $\begin{array}{c}\text { Criteria for the value-semantic } \\
\text { sphere of personality }\end{array}$ & $\begin{array}{c}\text { Learners } \\
1 \text { course }\end{array}$ & $\begin{array}{c}\text { Learners } \\
3 \text { course }\end{array}$ \\
\hline $\begin{array}{c}\text { materialwell-being } \\
\text { implementation of own } \\
\text { individuality, creativity and crea- } \\
\text { tivity }\end{array}$ & $71 \%$ & $21 \%$ \\
\hline $\begin{array}{c}\text { striving for change } \\
\text { surrounding reality }\end{array}$ & $69 \%$ & $14 \%$ \\
\hline $\begin{array}{c}\text { decision of certain } \\
\text { life tasks }\end{array}$ & $23 \%$ & $32 \%$ \\
\hline realization of one's social role & $11 \%$ & $63 \%$ \\
\hline
\end{tabular}

\section{Discussion}

The results of the study showed that the life values of $71 \%$ of first-year students were focused on material well-being, the realization of their own individuality and creative opportunities, and the desire to change the surrounding reality. While $63 \%$ of third-year students in the first place as the main reference points put the solution of certain life tasks, the realization of their social role.

These studies indicate the need to review the vector of measures carried out in accordance with the Fundamentals of State Policy aimed at minimizing nihilism. In the context of the introduction of digital technologies that provide access to legal information, minors relate the surrounding formations from the point of view of the law, focusing not on the process, but on the final result. However, the manifestations of the discrepancy between the legal reality and the fixed normative attitudes cause legal frustration, which often manifests itself in sthenic forms.

For example, the surveyed students identified the Internet (82\%), television $(79 \%)$, magazines and newspapers (41\%), laws (39\%), detective stories (37\%), personal observations $(34 \%)$, conversations with friends $(34 \%)$, educational activities $(31 \%)$, family conversations $(27 \%)$, feature films $(25 \%)$ as information sources about corruption.

The results of the study allowed us to come to a conclusion about the state of legal dissatisfaction of minors, due to the discrepancy between the theoretical provisions of the law and law enforcement at the active level of the value-semantic personal sphere. For the purpose of more in-depth scientific research, we believe it is appropriate to designate this social phenomenon as legal deprivation of minors. In particular, the American scientist Tr. Garr, studying the problems of people's participation in internal political conflicts, notes that deprivation, which consists in the complete or partial deprivation of the ability to meet basic needs, can cause aggression [6].

It should be agreed with E. A. Pevtsova that the problem of legal education aims specialists to solve the following tasks:

- building a competent, from a legal and pedagogical point of view, vertical legal training courses-from propaedeutics to professional legal education; 
- selection of legal information for its purposeful transfer to objects and subjects of the educational process, in order to form their pre-programmed skills of legal behavior, legal feelings and emotions;

- identification of effective technologies for the translation of legal content, taking into account individual, psycho-physiological characteristics of the individual [7].

Education is the acquisition of the capacity for intelligent self-determination and selfimprovement, the ability to develop one's own moral beliefs and to use one's own mind without the guidance of another person. Even the Swiss teacher I. G. Pestalozzi considered comprehensive general education as the education of the "head, heart and hand", i.e. the development of intelligence, the education of feelings and the formation of practical work skills [8].

We should agree with V. I. Andreev, who notes that the main thing in modern education and upbringing is the creative spiritual and moral self-development of the individual. Education will be effective if the integrity, the inseparable unity of education and upbringing, the unity of the goals, content and methods of education and training are achieved. In order to act effectively, the teacher must understand the goals that are defined in state documents, translate these goals into the language of pedagogical tasks; select the material on the basis of which educational interaction is carried out; choose appropriate methods, tools, and technologies to convey the cultural and value experience to students [9].

In this regard, the institution of legal interaction as a primary element of legal life deserves attention.

In sociology, social interaction is understood as a way of implementing social ties and relations in a system, which presupposes the presence of at least two subjects, the process of interaction itself, as well as the conditions and factors of its implementation, during which the formation and development of the individual, the social system takes place [10]. Legal interaction, like any social interaction, is informational in nature. The law fulfills its tasks due to the information and psychological impact on the individual, which is subject to the general laws of information and psychology [11]. At the same time, the legal norm and the legal text are not identical, the latter is a system of signs, the interpretation of which creates a certain legal meaning, aimed at regulating the behavior of subjects by determining their rights and legal obligations. A textual rule becomes a source of law when, in social reality, it corresponds to projected sociomental formations that give this rule a value, and corresponding social practices arise aimed at realizing the rights and legal obligations of communicating subjects. Thus, the legal norm is not in the text, but in the psychosociocultural reality, realized as an ideal-material phenomenon [12].

In the complex of methodological approaches developed in Russian pedagogy, the systemforming and adequate task of forming the anti-corruption culture of students is the methodology of the personality-oriented approach and the set of interrelated pedagogical principles of its implementation. Being the dominant methodology in the formation of an anti-corruption culture, the personality-oriented approach is used in combination with other well-proven approaches (axiological, competence-based, activity-based, culture-logical, reflexive). At the informative stage, cognitive-developing games should be used, at the orientation stage - plot-role-playing games and at the motivational-predictive stage business games that promote the effective assimilation of legal concepts and categories that develop their own positive attitude to the law, which is realized in the legitimate behavior of the student's personality [13].

In the course of the study, the authors conducted the following experiment. In the college, a control group of 1st-year students was identified, in which during the educational process during the semester, when studying disciplines and conducting educational work, an emphasis was placed on anti-corruption topics. Thus, when studying: works of art, 
corruption issues are touched upon (M. Y. Lermontov "The Death of a Poet"; He is not available to the ring of Gold! " V. Mayakovsky "Grafters", I. Krylov "The Fox and the Groundhog", etc.); The participants discussed measures to combat bribery in various historical periods (the meaning of the terms "promise", "wages", "red tape", Decrees of Catherine II on the publication of lists of bribe-takers, etc.); mathematicians solved problems on sentencing for such crimes as petty bribery, taking a bribe, giving a bribe, commercial bribery in the presence of mitigating or aggravating circumstances; competitions were held for the best campaign poster related to the anti-corruption topic, and the essay "How to defeat corruption"; crosswords containing the terms from legislative acts; Meetings with representatives of law enforcement agencies on anti-corruption issues were organized.

At the end of the semester, a survey of the control group and other college students was conducted. It was found that with an equal ratio of the number of students with a negative assessment of the phenomenon of corruption ( $96 \%$ and $91 \%$, respectively), only $3 \%$ of students in the control group allowed them to commit possible corruption in the future, while among students who were not in the control group, this indicator was $41 \%$.

\section{Conclusion}

Thus, the specificity of the content of legal education allows it to be implemented in the following forms: subject, inter-subject, educational, institutional, project. The most appropriate approach is an integrated approach that combines all of the above forms. It seems to be the most promising one, since it allows us to solve many urgent problems of modernizing a modern school: to increase the role of the educational component of the learning process and the development of students, to make the education of civic consciousness a single line of pedagogical influence.

Today, there is a state of legal dissatisfaction on the part of minors due to the divergence of theoretical provisions of the law and the application of the law at the active level of the personal value sphere. For the purpose of more in-depth scientific research, we believe it is appropriate to designate this social phenomenon as legal deprivation of minors. Legal life cannot be identified only with legal existence, it covers the spiritual sphere of the individual. The formation of the latter is associated with the system of educational activities within the state, including taking into account national, religious and other factors.

\section{References}

1. O.Y. Rybakov, Strategy of legal development of Russia: monograph, collective of authors (JUSTICIA, Moscow, 2015).

2. N.N. Voklenko, Legality and legal order (Volgograd, 2006).

3. A.I. Komarova, M.I. Bocharov, The emergence of anti-corruption thinking in the process of forming the core competencies of university students, Overcoming corruption is the main condition for the establishment of the rule of law: methodological, conceptual and theoretical, legal, analytical and predictive aspects. Interdepartmental Scientific Compendium 2 (40), 496-504 (2010).

4. G.K. Balabushevich, The formation of an anti-corruption consciousness among children in general education institutions, Overcoming corruption is the main condition for the establishment of a State governed by the rule of law. Interdepartmental Scientific Compendium 1 (39), 395-398 (2009). 
5. M.V. Shediy, Formation of anti-corruption legal awareness as a basic element of education of civil society, Middle Russian Gazette of Social Sciences, 2014.

6. W.L. Mason, The Journal of Politics 1, 228-229 (1977)

7. E.A. Pevtsova, Legal culture and legal education in Russia at the turn of the 20th-21st centuries (New textbook, Moscow, 2003).

8. K.M. Levitan, Legal Education: Textbook (Norma, Moscow, 2008).

9. I.N. Yemelyanova, Theory and Methods of Education: Study, Student Guide to Higher Education Institutions (Publishing Centre «Academy», Moscow, 2008).

10. I.A. Gromov, I.A. Matskevich, V.A. Semyonov, Western Sociology (DNA, SPB., 2003).

11. A.V. Malko, The legal life of modern Russian society: levels, slices, segments: monograph, paper. of Law. of Science, Prof. sasl.. (Jurlitinform, Moscow, 2016).

12. A.V. Polyakov, Communicative Conception of Law: Problems of Genesis and Legal Theoretic Basis: PhD Thesis, SPb., 2002.

13. S.V. Shiro, Formation of Orthodox Orthodoxy in the teaching of humanities among high school students, PhD Thesis, Volgograd, 1999. 